\title{
Sequential Changes in Red Cell Glycolytic Enzymes and Intermediates and Possible Control Mechanisms in the First Two Months of Postnatal Life in Lambs
}

\author{
S. F. TRAVIS, L. C. WAGERle, C. M. DE AlVARADO, G. ROSE, AND M. DELIVORIA- \\ PAPADOPOULOS \\ Department of Pediatrics and Cardeza Foundation for Hematologic Research, Jefferson Medical College, \\ Thomas Jefferson University and Departments of Pediatrics and Physiology, University of Pennsylvania School of \\ Medicine, Philadelphia, Pennsylvania
}

\begin{abstract}
The sequential changes in several glycolytic enzymes, glucose-6-phosphate dehydrogenase, glycolytic intermediates, and adenosine triphosphate, as well as intracellular pH and plasma inorganic phosphorus were followed simultaneously in eight lambs from birth to 2 months of age. The activities of all glycolytic enzymes and glucose6-phosphate dehydrogenase were elevated at birth. The 2,3-diphosphoglycerate concentration increased markedly postnatally and was associated with a simultaneous increase in the concentrations of red cell glucose-6-phosphate and total triose phosphate and a decrease in intracellular pH. Inorganic phosphorus also increased and correlated with the 2,3-diphosphoglycerate concentration in the first 10 days of postnatal life. The content of red cell 3-phosphoglycerate, 2-phosphoglycerate, phosphoenolpyruvate, and ATP increased slightly. These results suggested increased glycolytic flux through the diphosphoglycerate mutase reaction which resulted in net synthesis of 2,3 diphosphoglycerate. The red cell total triose phosphate peaked and fell initially, followed by glucose-6-phosphate and 2,3-diphosphoglycerate suggesting inhibition of phosphofructokinase activity and a decrease in glycolysis secondary to decreased red cell intracellular pH. After 10 days of postnatal life all glycolytic intermediates fell simultaneously, which correlated with a decrease in activity of the glycolytic enzymes. (Pediatr Res 19: 272-277, 1985)
\end{abstract}

Abbreviations

2,3-DP, 2,3-diphosphoglycerate

G-6-P, glucose-6-phosphate

F-6-P, fructose-6-phosphate

TTP, total triose phosphate

3-PG, 3-phosphoglycerate

2-PG, 2-phosphoglycerate

PEP, phosphoenolpyruvate

FDP, fructose diphosphate

DHAP, dihydroxyacetone phosphate

G-3-P, glyceraldehyde-3-phosphate

$\mathrm{Pi}$, inorganic phosphorus

Received March 15, 1984; accepted October 24, 1984

Send reprint requests to Dr. Susan F. Travis, Jefferson Medical College, Thomas Jefferson University, Department of Pediatrics, 1025 Walnut Street, Philadelphia, PA 19107.

Supported in part by NIH Grant HD-10213.

\author{
ALD, aldolase \\ HK, hexokinase \\ PK, pyruvate kinase \\ PFK, phosphofructokinase \\ DPGM, diphosphoglyceratemutase \\ PGK, phosphoglyceratekinase \\ ENO, enolase \\ G-6-PD, glucose-6-phosphate dehydrogenase \\ RBC, red blood cells \\ pHvc, intracellular pH
}

At birth, lambs are similar to human newborns since they possess a fetal $\mathrm{Hb}$ that has a high oxygen affinity $(1,3-6)$. Unlike the human, however, the lamb is capable of compensating for the presence of a high oxygen affinity $\mathrm{Hb}$ in the extrauterine environment by dramatically increasing the 2,3-DPG concentration $(1,3-6,13)$. Similar to humans, 2,3-DPG has a low affinity for fetal deoxyhemoglobin in sheep, so that the marked increase in 2,3-DPG does not result in improved oxygen delivery by binding to deoxy-fetal $\mathrm{Hb}$, but results in a decrease in intracellular $\mathrm{pH}$ which decreases $\mathrm{Hb}$ oxygen affinity via the Bohr effect (3). Unlike humans, both fetal and adult deoxyhemoglobins in sheep have a low affinity for 2,3-DPG but adult sheep $\mathrm{Hb}$ has an intrinsically low oxygen affinity which facilitates unloading of oxygen. It has been demonstrated that the dramatic rise in 2,3-DPG that occurs perinatally in lambs can be prevented by performing an exchange transfusion on the lamb with adult blood in the first few hours after birth (1). Thus, the rapid rise in 2,3-DPG in lambs in the first 2 days of life serves as a mechanism of lowering $\mathrm{Hb}$ oxygen affinity via the Bohr effect until an adequate amount of adult $\mathrm{Hb}$ is present. After the first 10 days of life, the 2,3-DPG concentration begins to decrease and usually falls to the minimal levels characteristic of adult sheep by 2 months of age (1,3-5). The fall in 2,3-DPG postnatally correlates inversely with the rise in adult sheep $\mathrm{Hb}(1)$.

Our laboratory has investigated the sequential changes in several red cell glycolytic enzymes, G-6-PD, glycolytic intermediates and ATP from birth until approximately 2 months of life (56-58 days), as well as intracellular $\mathrm{pH}$ and plasma $P_{i}$ in eight lambs simultaneously in order to determine the normal developmental pattern and to define the factors that influence the dramatic rise in 2,3-DPG that occurs in lambs during the first few days of postnatal life. 


\section{MATERIALS AND METHODS}

Cross-bred sheep were used. The lambs were born and housed at the University of Pennsylvania. Most births were nocturnal and unattended. The lambs were kept in small pens with their dams. Feeding consisted of dam's milk and some grain. Adult sheep were fed grain and hay. Approximately $6 \mathrm{ml}$ blood were obtained from each of eight lambs by jugular puncture on days $1,3,8,10,14-15,21,22,29-30,35-36,42-43,49-50,56-58$ of life. Two milliliters of whole blood were immediately pipetted into $4 \mathrm{ml}$ of chilled $2 \mathrm{~N}$ perchloric acid, reextracted, and neutralized by methods previously described (18). The concentrations of 2,3-DPG, ATP, G-6-P, F-6-P, TTP, 3-PG, 2-PG, and PEP were determined by methods previously described (18). TTP represents the simultaneous measurement of FDP, DHAP, and G-3-P as described by Keitt (8).

Aliquots for determination of intracellular and extracellular $\mathrm{pH}$ were removed when an adequate sample was obtained, and rapidly processed (2). The remaining blood was centrifuged, the plasma was removed, recentrifuged, and frozen for later determination of $\mathrm{Pi}$ (7). The packed cells were washed, filtered, and assayed for red cell glycolytic enzymes and G-6-PD, as previously described (19). Enzyme units were expressed as $\mu \mathrm{mol}$ of substrate converted $/ \mathrm{gHb} / \mathrm{min}$ at $37^{\circ} \mathrm{C}$. Data were analyzed statistically by linear regression (correlation coefficient).

\section{RESULTS}

Glycolytic enzymes and G-6-PD (Table 1). All glycolytic enzymes studied except ALD were elevated at birth and declined progressively throughout the first 2 months of life. The agedependent enzymes, HK, ALD, and PK transiently increased at 21-22 days of age and began to decrease again at 35-36 days of life. The mean decrease in HK activity from birth to 2 months of age was only $4 \%$ and $\mathrm{HK}$ activity was still $54 \%$ higher at $56-$ 58 days of age than in adult sheep whereas mean PK activity decreased $24 \%$ from birth to 2 months of life and was only $13 \%$ higher than adult sheep at 56-58 days. The most marked decrease in enzyme activity in the first 2 months of life was seen in PFK (64\%), DPGM (76\%), PGK (45\%), ENO (69\%), and G-6-PD
(46\%). Although mean PFK activity was similar to adult sheep by 56-58 days and mean PGK and ENO activities were only 14-15\% higher than in adult sheep, DPGM and G-6-PD activities were still 57 and 34\% higher, respectively, at 56-58 days of life, than in adult sheep.

Glycolytic intermediates and ATP. There were marked increases in the concentrations of G-6-P, F-6-P, TTP, and 2,3DPG with much less impressive increases in the concentrations of 3-PG, 2-PG, PEP, and ATP in the 1st wk of life when compared to adult sheep. The variation in the concentrations of these intermediates was so marked during this time period that the mean and SD for each day of sampling was not informative. For example, on day 1 the 2,3-DPG concentration varied from 475 to $6379.3 \mathrm{nmol} / \mathrm{ml} \mathrm{RBC}$; G-6-P varied from 50.5 to 624 $\mathrm{nmol} / \mathrm{ml} \mathrm{RBC}$, and TTP varied from 16.9 to $403 \mathrm{nmol} / \mathrm{ml} \mathrm{RBC}$. Thus, the data were presented individually for each lamb as the percentage of normal adult sheep values (Fig. 1-3). The adult sheep values used as controls are in Table 2 . Sequential changes in the concentrations of G-6-P, TTP, and 2,3-DPG were the most marked and are presented for each lamb. Changes in the concentration of F-6-P are not included since they followed the same pattern as the G-6-P. Since the changes in 3-PG, 2-PG, PEP, and ATP were of a lesser magnitude and tended to parallel each other, only 3-PG is presented. The numbers in parentheses represent intracellular $\mathrm{pH}$. Three patterns were observed (Figs. $1-3)$.

A. In lambs 1-4, the concentrations of G-6-P, TTP, and 2,3DPG increased simultaneously on day 1 , peaked between days 3-8, and tended to decrease simultaneously also, except lamb 3, whose red cell TTP concentration decreased significantly between days 3 and 8, whereas 2,3-DPG continued to increase and the G-6-P concentration was stable (Fig. 1).

B. In lambs 5 and 6 , the TTP concentration had already peaked on day 1 and fell significantly between days 1 and 3 as the concentrations of G-6-P and 2,3-DPG continued to increase (Fig. 2).

C. In lambs 7 and 8, the concentrations of G-6-P and TTP had already peaked on day 1 and both decreased in concentration between days 1 and 3. The concentration of 2,3-DPG was also

Table 1. Red cell enzyme activity* (U/g Hb) in neonatal lambs and adult sheep

\begin{tabular}{|c|c|c|c|c|c|c|c|c|c|c|c|c|}
\hline & \multicolumn{11}{|c|}{ Neonatal lambs $(n=8)$ (age in days) } & \multirow{2}{*}{$\begin{array}{c}\text { Adult } \\
\text { sheep } \\
(n=13)\end{array}$} \\
\hline & 1 & 3 & 8 & 10 & $14-15$ & $21-22$ & $29-30$ & $35-36$ & $42-43$ & $49-50$ & $56-58$ & \\
\hline $\mathrm{HK}$ & $\begin{array}{r}0.712 \\
\pm 0.256\end{array}$ & $\begin{array}{r}0.748 \\
\pm 0.243\end{array}$ & $\begin{array}{r}0.701 \\
\pm 0.122\end{array}$ & $\begin{array}{r}0.776 \\
\pm 0.123\end{array}$ & $\begin{array}{r}0.835 \\
\pm 0.167\end{array}$ & $\begin{array}{r}0.927 \\
\pm 0.306\end{array}$ & $\begin{array}{r}0.901 \\
\pm 0.306\end{array}$ & $\begin{array}{r}0.864 \\
\pm 0.240\end{array}$ & $\begin{array}{r}0.844 \\
\pm 0.212\end{array}$ & $\begin{array}{r}0.713 \\
\pm 0.257\end{array}$ & $\begin{array}{r}0.682 \\
\pm 0.158\end{array}$ & $\begin{array}{r}0.313 \\
\pm 0.102\end{array}$ \\
\hline PFK & $\begin{array}{r}5.22 \\
\pm 1.19\end{array}$ & $\begin{array}{r}5.01 \\
\pm 1.24\end{array}$ & $\begin{array}{r}4.61 \\
\pm 0.91\end{array}$ & $\begin{array}{r}4.12 \\
\pm 0.84\end{array}$ & $\begin{array}{r}3.89 \\
\pm 1.18\end{array}$ & $\begin{array}{r}3.38 \\
\pm 1.08\end{array}$ & $\begin{array}{r}3.02 \\
\pm 1.16\end{array}$ & $\begin{array}{r}2.49 \\
\pm 0.91\end{array}$ & $\begin{array}{r}2.12 \\
\pm 0.85\end{array}$ & $\begin{array}{r}2.06 \\
\pm 0.82\end{array}$ & $\begin{array}{r}1.90 \\
\pm 0.43\end{array}$ & $\begin{array}{r}1.96 \\
\pm 0.21\end{array}$ \\
\hline ALD & $\begin{array}{r}0.674 \\
\pm 0.109\end{array}$ & $\begin{array}{r}0.612 \\
\pm 0.111\end{array}$ & $\begin{array}{r}0.688 \\
\pm 0.167\end{array}$ & $\begin{array}{r}0.890 \\
\pm 0.277\end{array}$ & $\begin{array}{r}0.999 \\
\pm 0.171\end{array}$ & $\begin{array}{c}1.24 \\
\pm 0.217\end{array}$ & $\begin{array}{r}1.34 \\
\pm 0.29\end{array}$ & $\begin{array}{r}1.30 \\
\pm 0.28\end{array}$ & $\begin{array}{r}1.14 \\
\pm 0.33\end{array}$ & $\begin{array}{r}1.07 \\
\pm 0.22\end{array}$ & $\begin{array}{r}0.806 \\
\pm 0.104\end{array}$ & $\begin{array}{r}0.692 \\
\pm 0.144\end{array}$ \\
\hline PGK & $\begin{aligned} & 103.2 \\
\pm & 10.5\end{aligned}$ & $\begin{aligned} & 104.7 \\
\pm & 8.16\end{aligned}$ & $\begin{aligned} & 102.1 \\
\pm & 4.72\end{aligned}$ & $\begin{array}{r}97.0 \\
\pm 10.1\end{array}$ & $\begin{array}{r}92.9 \\
\pm 12.8\end{array}$ & $\begin{array}{r}89.0 \\
\pm 13.9\end{array}$ & $\begin{array}{r}85.2 \\
\pm 17.2\end{array}$ & $\begin{array}{r}72.8 \\
\pm 18.2\end{array}$ & $\begin{array}{r}71.0 \\
\pm 18.9\end{array}$ & $\begin{array}{r}61.9 \\
\pm 15.7\end{array}$ & $\begin{array}{r}57.1 \\
\pm 7.78\end{array}$ & $\begin{array}{r}48.6 \\
\pm 8.57\end{array}$ \\
\hline DPGM & $\begin{array}{r}1.96 \\
\pm 0.63\end{array}$ & $\begin{array}{r}1.84 \\
\pm 0.49\end{array}$ & $\begin{array}{r}1.72 \\
\pm 0.46\end{array}$ & $\begin{array}{r}1.59 \\
\pm 0.31\end{array}$ & $\begin{array}{r}1.41 \\
\pm 0.40\end{array}$ & $\begin{array}{r}1.24 \\
\pm 0.34\end{array}$ & $\begin{array}{r}0.874 \\
\pm 0.263\end{array}$ & $\begin{array}{r}0.800 \\
\pm 0.289\end{array}$ & $\begin{array}{r}0.705 \\
\pm 0.172\end{array}$ & $\begin{array}{r}0.613 \\
\pm 0.145\end{array}$ & $\begin{array}{r}0.481 \\
\pm 0.138\end{array}$ & $\begin{array}{r}0.205 \\
\pm 0.092\end{array}$ \\
\hline ENO & $\begin{array}{r}28.9 \\
\pm 8.02\end{array}$ & $\begin{array}{r}27.3 \\
\pm 6.88\end{array}$ & $\begin{array}{r}22.9 \\
\pm 6.89\end{array}$ & $\begin{array}{r}21.3 \\
\pm 6.45\end{array}$ & $\begin{array}{r}20.0 \\
\pm 6.34\end{array}$ & $\begin{array}{r}17.1 \\
\pm 6.48\end{array}$ & $\begin{array}{r}16.9 \\
\pm 3.96\end{array}$ & $\begin{array}{r}14.1 \\
\pm 6.82\end{array}$ & $\begin{array}{r}12.3 \\
\pm 6.07\end{array}$ & $\begin{array}{r}10.8 \\
\pm 4.89\end{array}$ & $\begin{array}{r}9.00 \\
\pm 2.99\end{array}$ & $\begin{array}{r}7.78 \\
\pm 2.95\end{array}$ \\
\hline PK & $\begin{array}{r}37.3 \\
\pm 13.5\end{array}$ & $\begin{array}{r}37.9 \\
\pm 10.8\end{array}$ & $\begin{array}{r}35.8 \\
\pm 10.5\end{array}$ & $\begin{array}{r}32.7 \\
\pm 7.63\end{array}$ & $\begin{array}{r}34.7 \\
\pm 9.55\end{array}$ & $\begin{array}{r}35.2 \\
\pm 9.48\end{array}$ & $\begin{array}{r}34.1 \\
\pm 9.09\end{array}$ & $\begin{array}{r}33.0 \\
\pm 7.21\end{array}$ & $\begin{array}{r}31.8 \\
\pm 5.65\end{array}$ & $\begin{array}{r}28.4 \\
\pm 5.46\end{array}$ & $\begin{array}{r}28.2 \\
\pm 4.22\end{array}$ & $\begin{array}{r}24.6 \\
\pm 3.08\end{array}$ \\
\hline G6PD & $\begin{array}{r}4.48 \\
\pm 1.31\end{array}$ & $\begin{array}{r}4.49 \\
\pm 0.93\end{array}$ & $\begin{array}{r}4.17 \\
\pm 0.70\end{array}$ & $\begin{array}{r}4.07 \\
\pm 0.61\end{array}$ & $\begin{array}{r}4.07 \\
\pm 0.49\end{array}$ & $\begin{array}{r}4.37 \\
\pm 0.85\end{array}$ & $\begin{array}{r}3.98 \\
\pm 0.88\end{array}$ & $\begin{array}{r}3.87 \\
\pm 0.86\end{array}$ & $\begin{array}{r}3.25 \\
\pm 0.59\end{array}$ & $\begin{array}{r}2.95 \\
\pm 0.56\end{array}$ & $\begin{array}{r}2.42 \\
\pm 0.28\end{array}$ & $\begin{array}{r}1.59 \\
\pm 0.31\end{array}$ \\
\hline
\end{tabular}

* Mean \pm SD. 

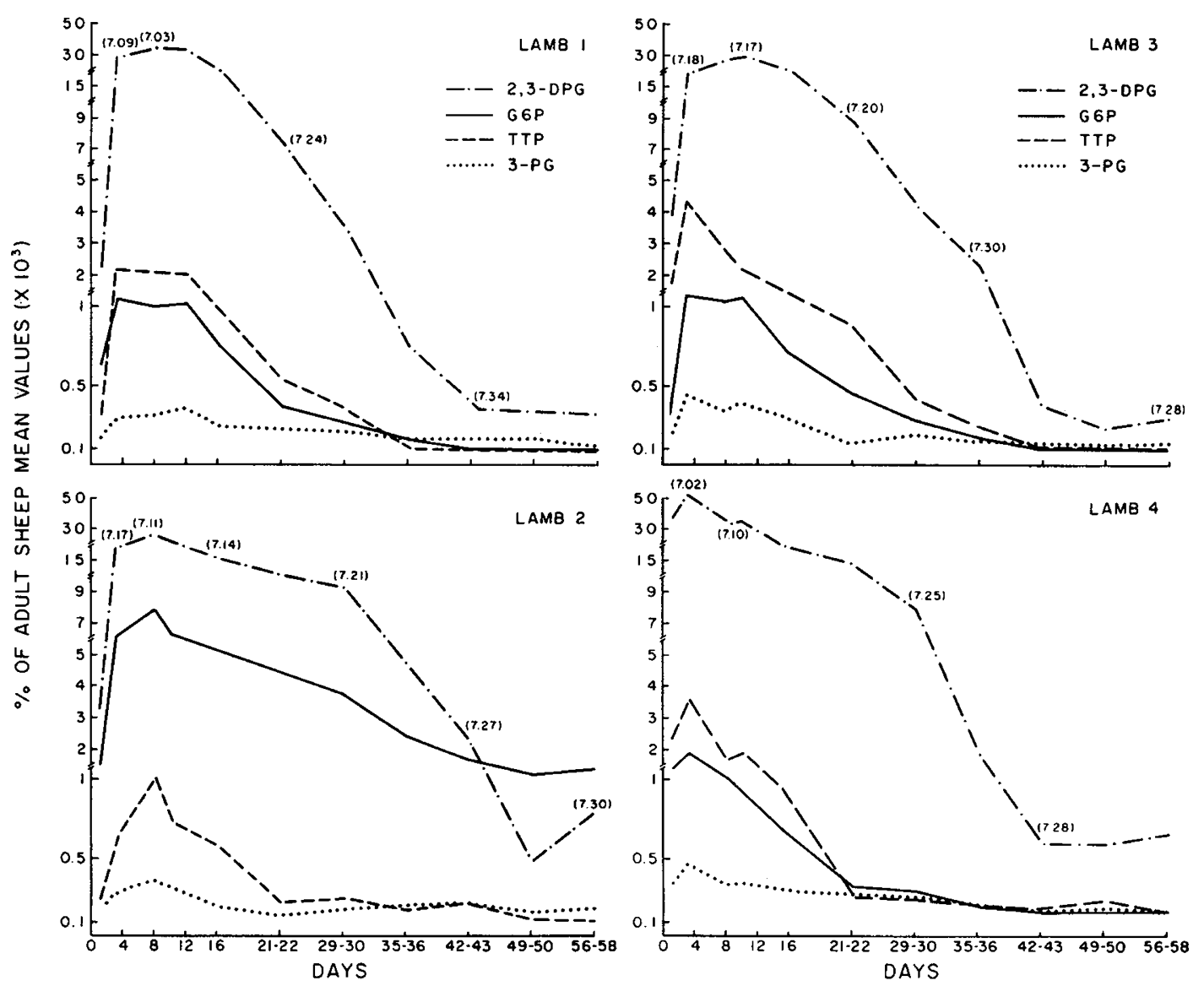

Fig. 1. Red cell glycolytic intermediates in postnatal lambs-pattern A.

markedly increased on day 1 and either remained relatively stable (lamb 8) or continued to increase further (lamb 7) between days 1 and 3 (Fig. 3).

After approximately 2 wk of postnatal life all red cell glycolytic intermediates tend to decrease simultaneously toward the low levels observed in adult sheep.

Red cell pHvc and plasma Pi (Table 3). The $\Delta \mathrm{pH}$ was significantly increased from days 3-10 which coincided with peak 2,3DPG levels and decreased pHvc. Plasma Pi was slightly higher than in adult sheep on days 1 and 3, progressively increased and peaked on day 10 and remained elevated the entire 2 months of postnatal life.

Possible control mechanisms. The concentration of red cell 2,3-DPG correlated inversely with $\mathrm{pHvc}$ from day 1 to 56-58 of life $(\mathrm{r}=-0.82 ; p<0.001$, Fig. 4). During the first 10 postnatal days, when 2,3-DPG was most elevated there was a positive correlation between Pi and 2,3-DPG ( $\mathrm{r}=0.66$; $p<0.001$; Fig. 5). After 10-14 days of life when all intermediates fell simultaneously, the decrease in 2,3-DPG from days 10 through 56-58 of postnatal life correlated positively with the decrease in DPGM activity $(\mathrm{r}=0.81 ; p<0.001$, Fig. 6$)$.

\section{DISCUSSION}

Red cell enzyme activity, the concentration of red cell glycolytic intermediates, red cell intracellular $\mathrm{pH}$, and plasma $\mathrm{Pi}$ have been measured simultaneously in lambs from birth to 2 months of postnatal life in order to document the sequential changes in glycolytic enzymes and intermediates toward normal adult sheep values, and to more clearly define the possible control mechanisms responsible for the marked postnatal rise and fall in the red cell 2,3-DPG concentration. Prior studies have not evaluated glycolytic enzymes and intermediates simultaneously, so that direct comparisons between enzyme activity and levels of glycolytic intermediates could not be made.

At birth the activities of HK, PFK, PGK, DPGM, ENO, PK, and G-6-PD were elevated when compared to adult sheep, and decreased in activity throughout the first 2 months of life. Red cell PFK, DPGM, PGK, ENO, and G-6-PD demonstrated the most marked decrease in activity from birth to 2 months of age (46-76\%). Red cell PFK, PGK, ENO, and PK activities approached adult values by 2 months of age but DPGM activity remained $57 \%$ higher than in adult sheep, despite a $75 \%$ decrease in enzyme activity between days 1 and 58 of life. These results are similar to those reported by Noble et al. (12) in sheep during the first 17 days of postnatal life, with the exception of PK activity which was similar in newborn and adult sheep in their study.

Thus, newborn lambs have markedly elevated levels of enzymes involved in the synthesis of 2,3-DPG and other glycolytic intermediates. In the first 3 days of life, the concentration of red cell 2,3-DPG increases markedly and peaks at levels 250-460 times greater than that observed in adult sheep (adult mean 21.2 $\mathrm{nmol} / \mathrm{ml} \mathrm{RBC}$; peak in lambs ranged from 4821-9800 $\mathrm{nmol} / \mathrm{ml}$ $\mathrm{RBC})$, which is similar to results obtained by others $(1,3-5,13)$. This rapid rise in 2,3-DPG was associated with a significant increase in $\Delta \mathrm{pH}$ secondary to a decrease in intracellular $\mathrm{pH}$ from days 3 to 10 which coincided with peak 2,3-DPG levels, similar to prior studies (3). From 10 days to 2 months of life, as the levels of 2,3-DPG decreased significantly toward the low levels observed in adults, there was a corresponding decrease in DPGM activity. There was also a positive, but less impressive, correlation between the decrease in PFK activity and the TTP concentration from 10 to 58 days of postnatal life $(r=0.45 ; p<0.001)$. The decrease in the 2,3-DPG concentration after 10 days of life was associated with an increase in intracellular $\mathrm{pH}$. Thus, there was 
a significant inverse correlation $(p<0.001)$ between intracellular $\mathrm{pH}$ and the red cell 2,3-DPG content throughout the first 2 months of postnatal life.

Plasma $\mathrm{Pi}$ was also evaluated sequentially and appeared to influence the concentration of red cell 2,3-DPG since there was a significant positive correlation between plasma $\mathrm{Pi}$ and red cell 2,3-DPG during the first 10 postnatal days when the 2,3-DPG concentration was most elevated. These results are consistent with the known effects of $\mathrm{Pi}$ on red cell metabolism and have been described previously $(9-11,14,15,16,20)$.

The marked increase in red cell 2,3-DPG content in early postnatal life was also associated with a marked increase in G-6P, F-6-P and TTP (simultaneous measurement of FDP, DHAP, and G-3-P), whereas the concentrations of 3-PG, 2-PG, PEP, and ATP increased slightly. This pattern of glycolytic intermediates was suggestive of an increased glycolytic rate with preferential flow through the DPGM step, rather than the PGK reaction, resulting in net synthesis of 2,3-DPG. The increase in the 2,3-DPG concentration was associated with a decrease in red cell $\mathrm{pHvc}$ and it is proposed that this decrease in $\mathrm{pH}$ then led to inhibition of PFK activity and a resultant decrease in the concentration of TTP and a decrease in the glycolytic rate. A crossover at the PFK step was demonstrated by the simultaneous decrease in the red cell TTP concentration and increase in the G-6-P (and F-6-P) concentrations in lambs 5 and 6, and in lamb

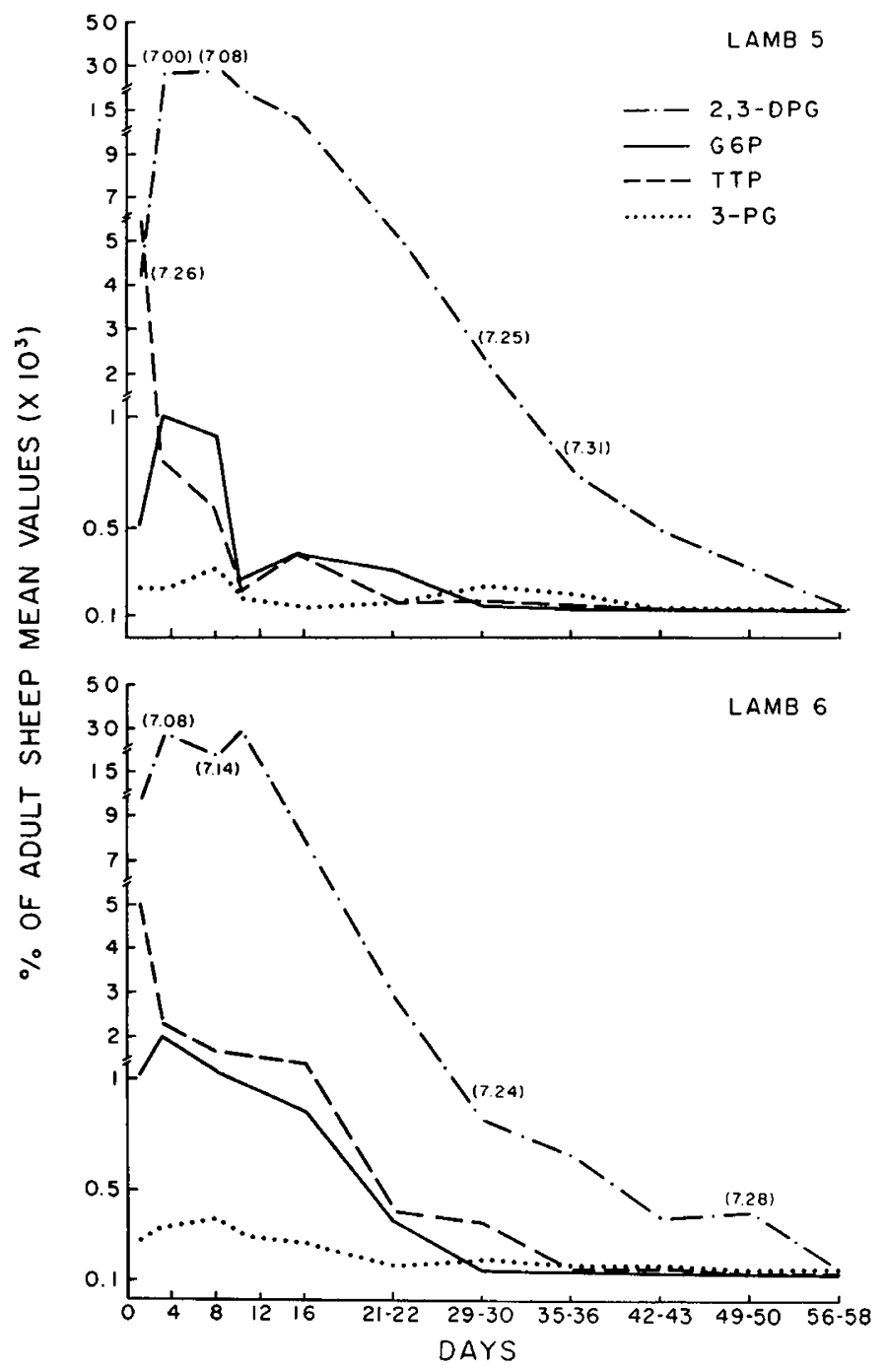
B.

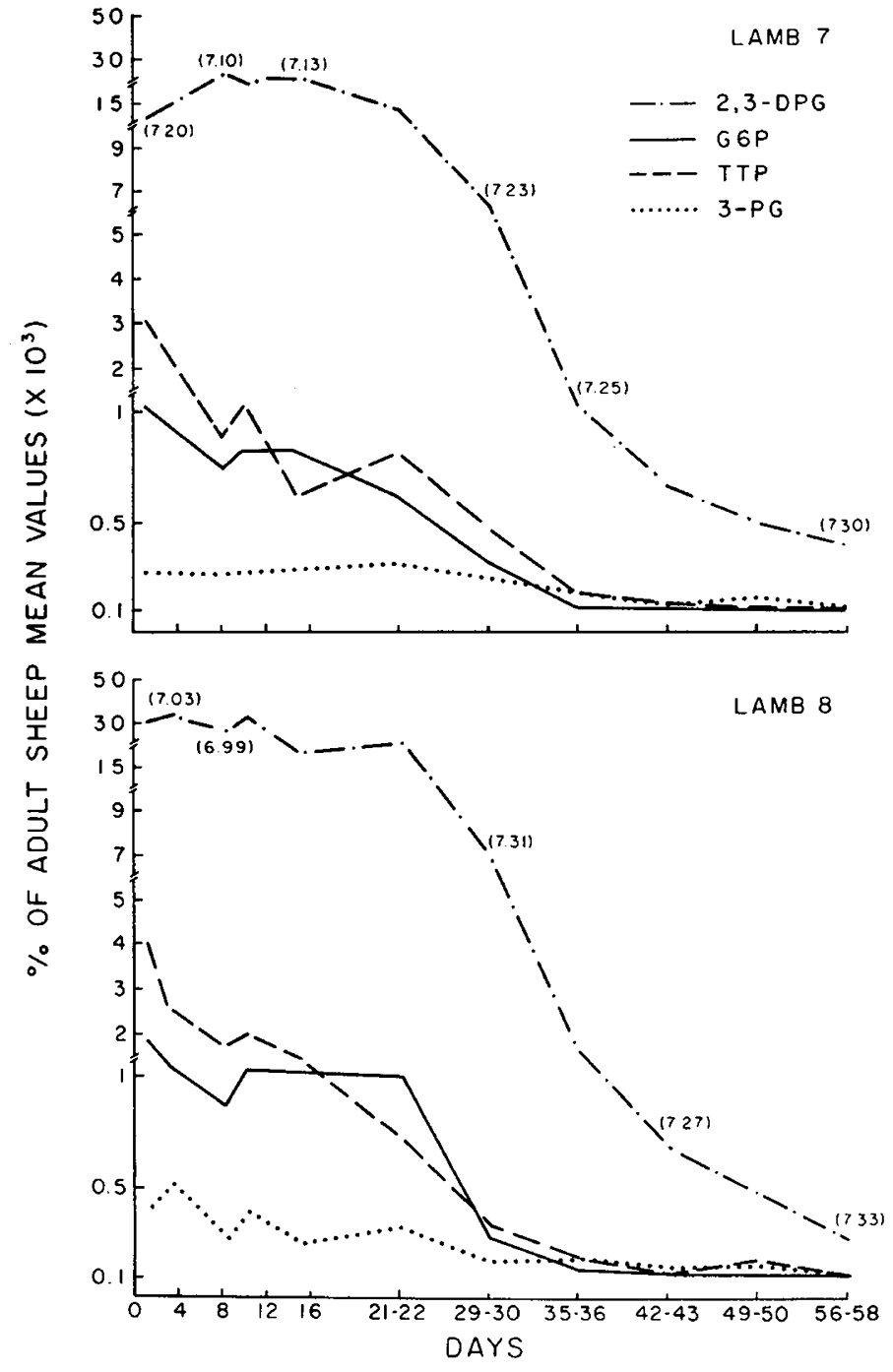

Fig. 3. Red cell glycolytic intermediates in postnatal lambs-pattern C.

Table 2. Red cell glycolytic intermediates* and ATP $(\mathrm{nmol} / \mathrm{ml}$ $R B C)$ in adult sheep $(n=13)$

\begin{tabular}{lc}
\hline G-6-P & $34.2 \pm 8.47$ \\
F-6-P & $9.50 \pm 2.62$ \\
TTP & $7.21 \pm 2.19$ \\
2,3-DPG & $21.2 \pm 16.2$ \\
3-PG & $20.4 \pm 5.16$ \\
2-PG & $4.44 \pm 2.70$ \\
PEP & $9.16 \pm 4.60$ \\
ATP & $532 \pm 126$ \\
\hline
\end{tabular}

* Mean \pm SD.

3 , the TTP concentration also decreased prior to the fall in the G-6-P concentration. It is likely that the three different patterns of glycolytic intermediates that were observed (A, B, and C) represented differences in the time the samples were drawn in relation to the birth of the lambs, and to the stimulus to glycolysis, since the birth of the lambs was nocturnal and unattended in most instances. For example, in pattern $C$ the greatest time interval had probably elapsed between the stimulus to glycolysis and day 1 blood sampling, since the concentrations of G-6-P, TTP, and 2,3-DPG had already peaked and were decreasing. In pattern B, only the TTP was falling which was consistent with inhibition of PFK activity secondary to decreased intracellular 
Table 3. Serum $P_{\mathrm{i}}$, whole blood $p H(p H v), p H v c$, and $\Delta p H$ in neonatal lambs and adult sheep

\begin{tabular}{ccccc}
\hline Age in days & $\mathrm{P}_{\mathrm{i}}(\mathrm{mg} / \mathrm{dl})^{*}$ & $\mathrm{pHv}$ & $\mathrm{pHvc}^{*}$ & $\Delta \mathrm{pH}^{*}$ \\
\hline Lambs & & & & \\
1 & $7.55 \pm 1.14$ & $7.419 \pm 0.080$ & $7.235 \pm 0.049$ & $0.184 \pm 0.040$ \\
3 & $7.55 \pm 3.16$ & $7.420 \pm 0.061$ & $7.088 \pm 0.069$ & $0.332 \pm 0.070$ \\
8 & $8.99 \pm 1.29$ & $7.388 \pm 0.083$ & $7.088 \pm 0.058$ & $0.300 \pm 0.040$ \\
10 & $9.51 \pm 0.50$ & $7.404 \pm 0.079$ & $7.126 \pm 0.043$ & $0.278 \pm 0.060$ \\
15 & $9.00 \pm 1.31$ & $7.419 \pm 0.090$ & $7.172 \pm 0.076$ & $0.247 \pm 0.045$ \\
$21-22$ & $9.41 \pm 1.04$ & $7.409 \pm 0.068$ & $7.210 \pm 0.045$ & $0.199 \pm 0.036$ \\
$29-30$ & $9.53 \pm 0.92$ & $7.431 \pm 0.043$ & $7.246 \pm 0.030$ & $0.185 \pm 0.036$ \\
$35-36$ & $9.96 \pm 1.15$ & $7.409 \pm 0.061$ & $7.251 \pm 0.068$ & $0.158 \pm 0.023$ \\
$42-43$ & $8.51 \pm 3.28$ & $7.437 \pm 0.061$ & $7.266 \pm 0.059$ & $0.171 \pm 0.020$ \\
$49-50$ & $8.74 \pm 1.18$ & $7.415 \pm 0.048$ & $7.263 \pm 0.049$ & $0.152 \pm 0.013$ \\
$56-58$ & $8.81 \pm 1.70$ & $7.426 \pm 0.075$ & $7.260 \pm 0.070$ & $0.166 \pm 0.020$ \\
Adult sheep & $7.31 \pm 1.30$ & $7.415 \pm 0.038$ & $7.259 \pm 0.029$ & $0.156 \pm 0.026$ \\
\hline
\end{tabular}

* Mean \pm SD.

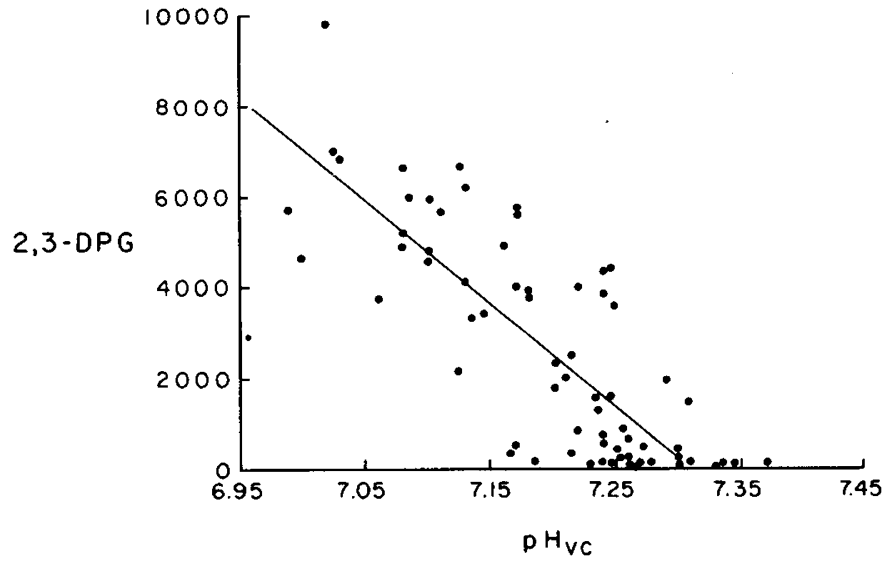

Fig. 4. Relationship between red cell 2,3-DPG concentration (nmol/ $\mathrm{ml} \mathrm{RBC}$ ) and red cell intracellular $\mathrm{pH}(\mathrm{pHvc})$ from day 1 to $56-58$ of postnatal life $(n=74 ; \mathrm{r}=-0.82 ; p<0.001)$.

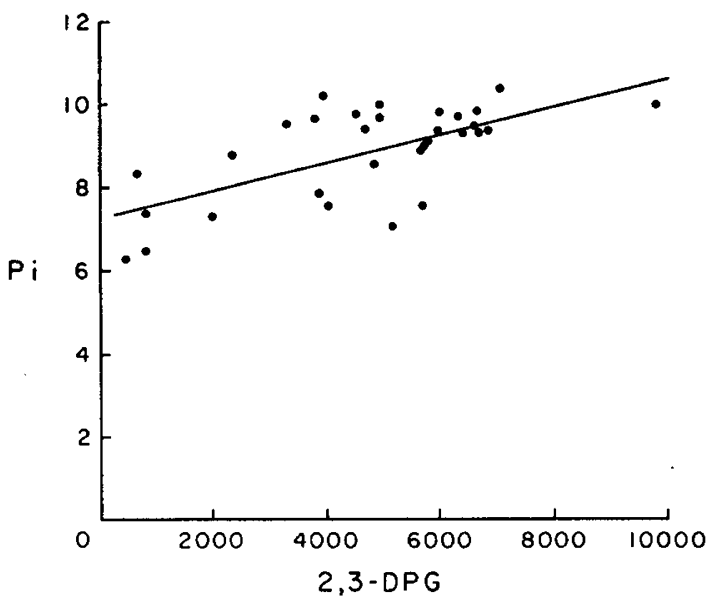

Fig. 5. Relationship between red cell 2,3-DPG concentration (nmol/ $\mathrm{ml} \mathrm{RBC}$ ) and plasma inorganic phosphorus ( $\mathrm{Pi}$ in $\mathrm{mg} / \mathrm{dl}$ ) in the first 10 days of postnatal life. $(n=31 ; \mathrm{r}=0.66 ; p<0.001)$.

$\mathrm{pH}$ and the stimulus to glycolysis presumably occurred closer to the time of blood sampling than in C. Pattern A probably represented the most recent events with a simultaneous increase in all three intermediates.

Pattern A was suggestive that 2,3-DPG inhibition of red cell hexokinase activity, as previously described by Srivastava and Beutler (17), may also have contributed to the pattern of glycol-

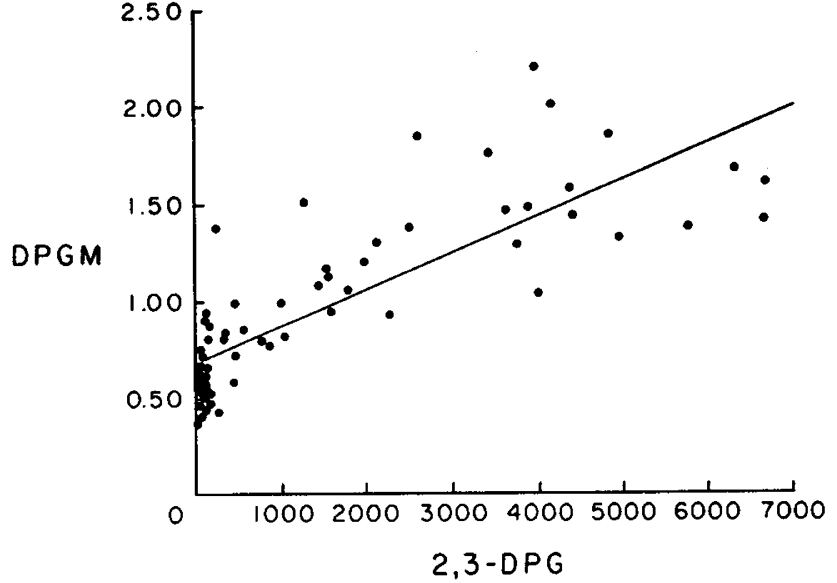

Fig. 6. Relationship between red cell 2,3-DPG concentration (nmol/ $\mathrm{ml} \mathrm{RBC}$ ) and DPGM activity (U/g Hb) from days 10 to $56-58$ of postnatal life. $(n=64 ; \mathrm{r}=0.81 ; p<0.001)$.

ytic intermediates observed, especially in lambs 1,2 , and 4 in whom the concentrations of G-6-P, TTP, and 2,3-DPG increased and fell simultaneously. However, an inverse correlation between the red cell 2,3-DPG concentration and hexokinase activity could not be demonstrated.

In recent studies, Noble et al. (13) postulated activation of PFK as the stimulus to glycolysis in newborn lambs. Our results differ from those of Noble et al. (13) who found the rise of TTP always preceded the increase in 2,3-DPG and they also postulated a partial block at the glyceraldehyde-3-phosphate dehydrogenase step which was relieved as the concentration of serum $\mathrm{Pi}$ increased. The simultaneous increase in G-6-P, TTP, and 2,3-DPG in our studies is more suggestive of activation of PFK and preferential flow through the DPGM step, as the mechanism responsible for the pattern of glycolytic intermediates observed. The differences in the results may be secondary to species variation in the sheep studied.

The stimulus to glycolysis at birth has been proposed to be a rise in venous $\mathrm{pH}$ shortly after birth, which leads to activation of PFK, and an increase in plasma glucose which supplies increased substrate for the fetal red cell (13). It is proposed on the basis of our studies that this increased glycolytic rate results in net synthesis of 2,3-DPG due to preferential flow through the DPGM step. The dramatic increase in the concentration of red cell 2,3-DPG is self-limited since it results in a decrease in intracellular $\mathrm{pH}$ which appears to inhibit PFK activity resulting in a decrease in the TTP concentration and glycolytic rate, which was followed by a decrease in all glycolytic intermediates. Inhi- 
bition of $\mathrm{HK}$ activity by $2,3-\mathrm{DPG}$ may also have contributed to the decrease in the concentration of G-6-P and other intermediates distal to this step. The magnitude of the increase in the 2,3DPG concentration was probably further enhanced by the increasing plasma Pi concentration. After the first 10-14 days of life all glycolytic intermediates fell simultaneously. At this time other control mechanisms became operative since glycolytic enzyme activities were also decreasing, as demonstrated by the significant correlation between the decreasing activity of red cell DPGM and corresponding decrease in the red cell 2,3-DPG concentration.

These studies have demonstrated that red cell PFK plays a key regulatory role in postnatal life in lambs. Thus, the fetal lamb can serve as a model for the study PFK activation and inhibition in vivo and the regulation of 2,3-DPG synthesis.

\section{REFERENCES}

1. Bard H, Fouron JC, Grothe AM, Soukini MA, Cornet A 1976 The adaptation of the fetal red cells of newborn lambs to extrauterine life: the role of 2,3diphosphoglycerate and adult hemoglobin. Pediatr Res 10:823

2. Battaglia FC, Behrman RE, Hellegers AE, Battaglia JD 1965 Intracellular hydrogen ion concentration changes during acute respiratory acidosis and alkalosis. J Pediatr 66:737

3. Battaglia FC, McGaughey H, Makowski EL, Meschia G: 1970 Postnatal changes in oxygen affinity of sheep red cells: a dual role of diphosphoglyceric acid. Am J Physiol 219:217

4. Baumann R, Bauer CH, Rathschlag-Shaefer AM 1972 Causes of the postnatal decrease of blood oxygen affinity in lambs. Respir Physiol 15:151

5. Blunt MH, Kitchens JL, Mayson SM, Huisman THJ 1971 Red cell 2,3diphosphoglycerate and oxygen affinity in newborn goats and sheep. Proc Soc Exp Biol Med 138:800

6. Bunn FH 1981 Evolution of mammalian hemoglobin function. Blood 58:189

7. Fiske CH, Subbarow Y 1925 The colorimetric determination of phosphorus. J
Biol Chem 66:375

8. Keitt AS 1969 Hemolytic anemia with impaired hexokinase activity. J Clin Invest 48:1997

9. Lichtman MA, Miller DR 1970 Erythrocyte glycolysis, 2,3-diphosphoglycerate and adenosine triphosphate concentration in uremic subjects: relationship to extracellular phosphate concentration. J Lab Clin Med 76:267

10. Lichtman MA, Miller DR, Cohen J, Waterhouse C 1971 Reduced red cell glycolysis, 2,3-diphosphoglycerate and adenosine triphosphate concentration and increased hemoglobin-oxygen affinity caused by hypophosphatemia. Ann Intern Med 74:562

11. Minakami S, Yoshikawa H 1965 Inorganic phosphate and erythrocyte glycolysis. Biochim Biophys Acta 99:175

12. Noble NA, Cabalum TC, Nathanielsz PW, Tanaka KR 1982 Erythrocyte enzymes in sheep: comparison of activity in fetal, newborn, maternal and non-pregnant ewe erythrocytes. Biol Neonate 41:161

13. Noble NA, Jansen CAM, Nathanielsz PW, Tanaka KR 1983 Mechanism of red cell 2,3-diphosphoglycerate increase in neonatal lambs. Blood 61:920

14. Rapoport S, Guest GM 1938 Changes of organic acid-soluble phosphorus, diphosphoglycerate, adenosine triphosphate, and inorganic phosphorus in blood cells of rats during the development and healing of rickets. J Biol Chem 126:749

15. Rizzo SC, Eckel RE 1966 Control of glycolysis in human erythrocytes by inorganic phosphate and sulfate. Am J Physiol 211:429

16. Rose IA, Warms JVB, O'Connell EL 1964 Role of inorganic phosphate in stimulating the glucose utilization of human red blood cells. Biochem Biophys Res Commun 15:33

17. Srivastava SK, Beutler E 1972 The effect of normal red cell constituents on the activities of red cell enzymes. Arch Biochem Biophys 148:249

18. Travis SF, Kumar SP, Delivoria-Papadopoulos M 1981 Red cell metabolic alterations in postnatal life in term infants: glycolytic intermediates and adenosine triphosphate. Pediatr Res 15:34

19. Travis SF, Kumar SP, Paez PC, Delivoria-Papadopoulos M 1980 Red cell metabolic alterations in postnatal life in term infants: glycolytic enzymes and glucose-6-phosphate dehydrogenase. Pediatr Res 14:1349

20. Travis SF, Sugerman HJ, Ruberg RL, Dudrick SJ, Delivoria-Papadopoulos M, Miller LD, Oski FA 1971 Alterations of red cell glycolytic intermediates and oxygen transport as a consequence of hypophosphatemia in patients receiving intravenous hyperalimentation. N Engl J Med 285:763

\title{
Epidermal Growth Factor Binding to Neonatal Mouse Skin Explants and Membrane Preparations-Effect of Triiodothyronine
}

\author{
S. B. HOATH, ${ }^{1}$ J. LAKSHMANAN, AND D. A. FISHER \\ Department of Pediatrics, Harbor-UCLA Medical Center, UCLA School of Medicine, Torrance, California 90509
}

\begin{abstract}
Daily treatment of newborn Swiss-Webster mice with triiodothyronine (T3, $500 \mathrm{ng} /$ day) increased epidermal growth factor (EGF) content in whole skin (epidermis + dermis). Separation of the epidermis using 0.01 $\mathrm{M}$ dithiothreitol followed by processing for radioimmuno-
\end{abstract}

Received July 20, 1984; accepted October 24, 1984.

Reprint requests Dr. Steven B. Hoath, Department of Pediatrics, University of Cincinnati Medical Center, Mail Location 541, Room 6263, 231 Bethesda Avenue Cincinnati, OH 45267.

This work was supported by Grants HD-04270, HD-07013 from The National Institute of Child Health, and Human Development of The National Institute of Health.

A preliminary report of these findings was presented at the 29th Annual Meeting of the Western Association of Physicians, February 1984.

' Current address: Department of Pediatrics, ML 541, University of Cincinnati College of Medicine, Cincinnati, OH 45267. assay measurement reveals levels of EGF 2-to 3-fold higher in epidermis than in whole skin. In vitro flotation of circular skin sections from control and T3 treated neonatal mice in medium containing $\left[{ }^{125}\right]$ EGF showed increased uptake of label following 5 days of in vivo T3 treatment. Mouse skin membrane preparations exhibit saturable, specific binding of $\left[\mathrm{I}^{125}\right]$ EGF. T3 treatment for 5 days in vivo significantly increased EGF binding capacity in skin membrane preparations but did not alter EGF receptor affinity (Kd $4.5 \mathrm{nM}$ ). Protein, RNA, and DNA concentrations were significantly increased in whole neonatal mouse skin following $\mathrm{T3}$ administration. These results suggest one mechanism by which thyroid hormones increase skin EGF concentration is augmentation of skin EGF receptor binding. (Pediatr Res 19: 277-281, 1985) 